\title{
脳損傷後の微小血管構築の経時的観察
}

\section{織田 哲至}

\section{Changes in Brain Microvascular Architecture following Experimental Cold Injury}

\section{Tetsuji ORITA}

Department of Neurosurgery, Yamaguchi University, Ube, Yamaguchi

\begin{abstract}
Sequential changes in the microvascular architecture of rat brains following local freezing injury were studied by scanning electron microscopy involving the cerebrovascular casting method. Repair of the microvascular architecture was initiated on day 3 after injury. Hematogenous cells and reactive astrocytes within the edematous zone participated in the regenerative process. The microvascular architecture was reconstructed from the edge of the lesion toward the brain surface. On the other hand, in small parts of the brain surface subjected to severe, focal freezing, the microvascular architecture was newly formed and resembled that of fetal and newborn rat cortices. Within 7 days after injury, the microvascular architecture was completely repaired.
\end{abstract}

Key words: microvascular architecture, scanning electron microscopy, vascular casting, brain edema, cold injury

\section{I はじめに}

脳浮腫の血管についての形態学的な面からの多くの研究 は，急性期の血管透過性に焦点が当てられている。しかし 最近, 脳浮腫を病巣修復の過程として捉えた研究》や浮 腫液の消長経路に関する研究 $8,15,18)$ など，慢性期にも目が 向けられるよらになった。この時期の血管系についての研 究3) 俚少なく、その形態，特に血管構築については汪とん ど不明でるる。私は脳損傷啳に伴ら脳浮腫時の血管構築を 経時的かつ立体的比観察し，病巣修復といら面加ら考察し たので報告する。

\section{II 方法}

体重200〜250 gの Wistar 系ラットをネンブタール静注 $(40 \mathrm{mg} / \mathrm{kg})$ により麻酔して, 硬膜に損傷を与光ないよう 儿径 $3 \mathrm{~mm}$ の小開頭を設けたそこよりドライアイスとア 七トンにて冷却 $\left(-78^{\circ} \sim 80^{\circ} \mathrm{C}\right)$ した金属棒を硬膜外に15秒
間当て，凍結脳損傷を作製した，損傷 1，2，3，5，7 日後， おのおの 5 匹ずつを対象とした。

浮腫の程度みるために，屠殺 1 時間前に $2 \%$ エバンス ブルー $(2 \mathrm{~m} l / \mathrm{kg})$ を経静眽的に投与した。年の後, 人上呼 吸下に開腹・開胸老行った。下行大動脈結禁後，ただら にカニューレを左心室入㨉入し，右心耳の切断と同時に $37^{\circ} \mathrm{C}$ の生食約 $400 \mathrm{cc}$ を $100 \sim 120 \mathrm{mmHg}$ の生で注入し, 血 液を流出させた。カニューレを大動脈起始部に進め, 固定 し， $37^{\circ} \mathrm{C}$ ○ $10 \%$ buffered formalinを，つてて動物を冷却さ 也る目的で $4{ }^{\circ} \mathrm{C} の 10 \%$ buffered formalin 同圧にて注入 し，灌流固定を行った。

固定後, レジン(Mercox CL-2Rに polymeliger 40 対 1 の割合で混合) $4 \mathrm{ml} / \mathrm{min}$ の速度でカニューレから注入 し, 硬化後, 約 $5 \sim 10 \mathrm{~mm}$ 厚のスライスに切り出した。次 に, Yoshida こ20)の方法に準じ，以下の操作を行った。 そ のスライスを $20 \% \mathrm{NaOH}$ 液に一晚浸漬し， $0.5 \% \mathrm{NaClO}$ 液にて約 2 週間かけて脳組織を溶解させた。その血管鋳型

Address reprint requests to: T. Orita, M.D., Department of Neurosurgery, Yamaguchi University, 1,144 Kogushi, Ube, Yamaguchi 755.

受稿 1986 年10月22日 受理 1987 年 7 月27日 
を苲留水にて十分洗滌し，液体絰素にて急速凍結传，真空 乾燥させた。試料をスバッタコーティング(Eiko IB-3 Ion Coater) L, 走査電顕 JSM-T300 (JEOL-Technics Co.

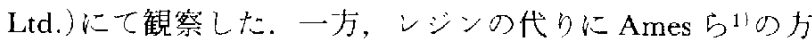
法により作製したゼラチン加コロイダルカーボンを同様の 方法にて灌流周定したのち注入し， microslicerにて 100 $\mu \mathrm{m}$ 切片として血管鋳型と比較観察した。

\section{III 結 果}

浮腫の程度は，エハンンスブル一の血管外漏出の強さによ
门観察した。去の結果，浮腫は1日日にもっとも强く，7 日十には注消失した。

1 日十の浮腫内の向管数は非常に少なく，毛細血管網は はとんと双られず，残っている血管仗值線走行を示した。 時に $5 \mu \mathrm{m}$ 前徭の血管が名られたが，九の辟心不整で，珠 数玉状を古していた。2 日日の所見も1 日月乞大差はなか った。

3 月目になると，浮腫周辺上り睡存の血管構築を再現卞 る形で，毛細血管網が浮腫の中心を取り曲むよら飞出現し てをた（Fig.1）。しかし，毛細血管網は非常以䠅であり，

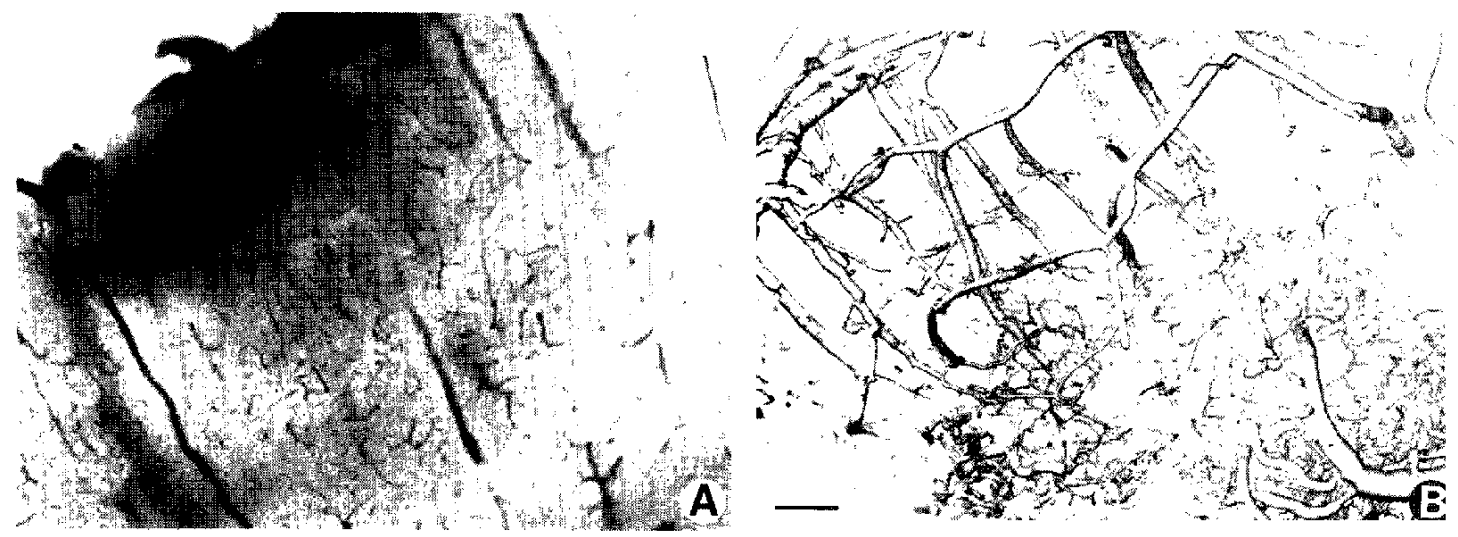

Fig. 1 Day 3 after cold injury. Repair of the microvascular architecture begins at the edge of the lesion and advances toward the brain surface. A: Microvasculature demonstrated by colloidal carbon. $\times 40$. B: Scanning electron microgram of vascular cast. Bar $=100$ $\mu \mathrm{m}$.
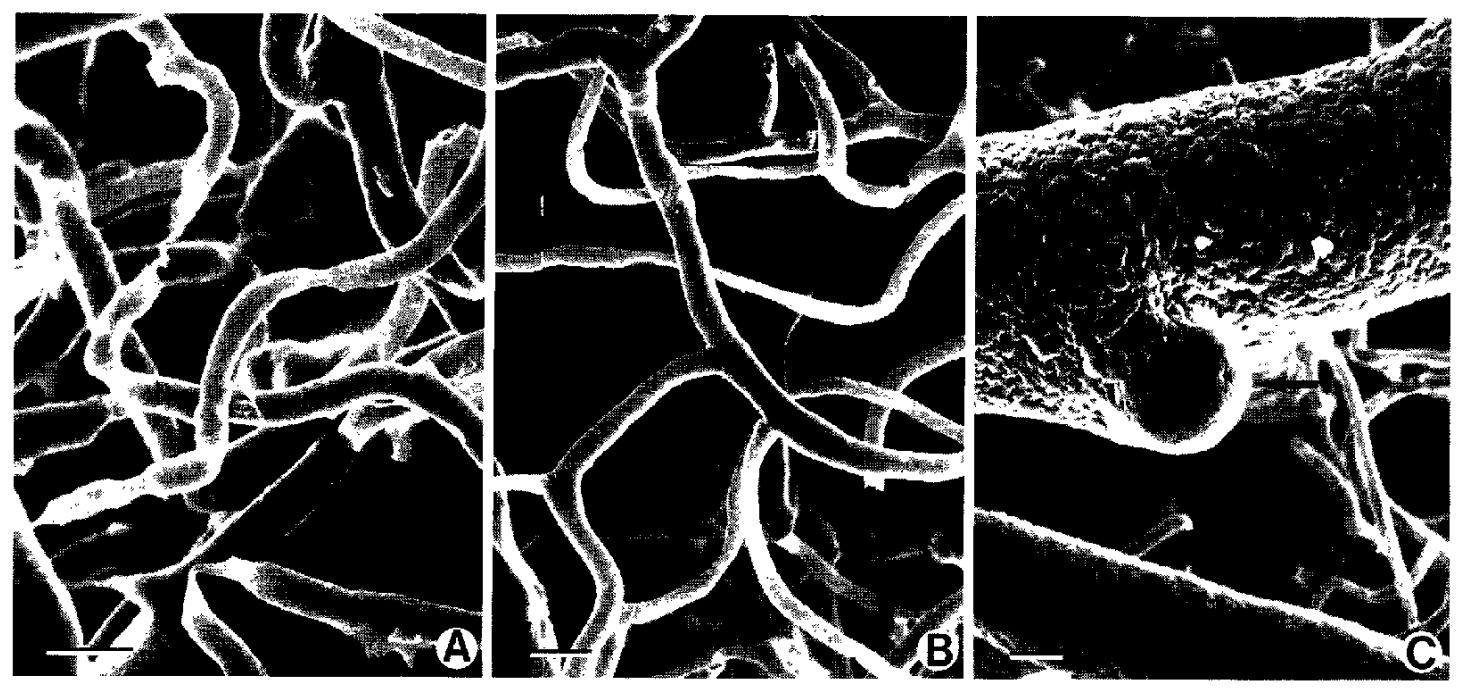

Fig. 2 Scanning electron micrograms of vascular cast obtained on day 3 after cold injury. A, B: Many capillarics with irregular walls are seen in the margin of the edematous zone, $\mathrm{Bar}=10 \mu \mathrm{m}$. C: A blood vessel at the brain surface exhibits a sprouting branch (arrow) . $\operatorname{Bar}=10 \mu \mathrm{m}$. 


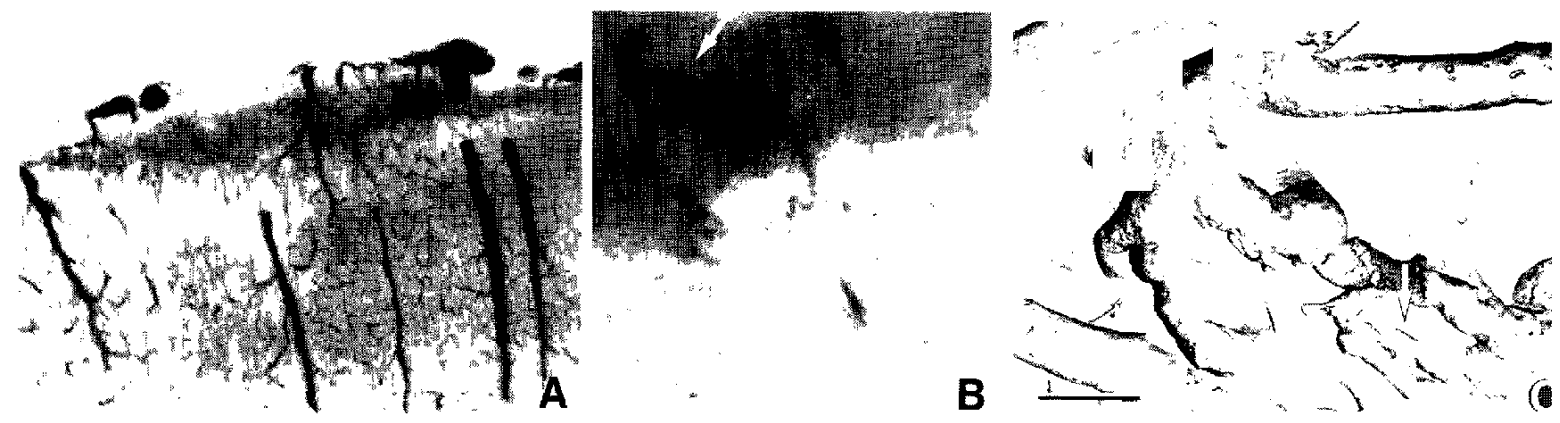

Fig. 3 Day 5 after cold injury. A, B: Microvascular architecture demonstrated by colloidal carbon. Tortuous, irregular vcssels (arrow) are seen at the brain surface. A: $\times 40, B: \times 200$. C: Scanning electron microgram of vascular cast showing dilated, tortuous vessels at the brain surface, with many nodular protrusions and septal formation (arrow). Bar $=100 \mu \mathrm{m}$.

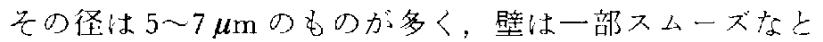
ころ女みられるが，多く林不整であった(Fig. 2A, B)。束 た，皮質に対して長軸力向の30 50 $\mu \mathrm{m}$ 径の血管が早期に 出現してくる傾向に吉った（Fig.1B）。その的，脳表近

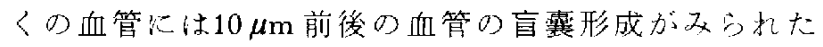
(Fig. 2C).

5 日日になると, 脳表近くに搪焉・蛇行の日立つ50 $\mu \mathrm{m}$ 前後の血管が出現してきたが，その表面構造は付皮細胞の

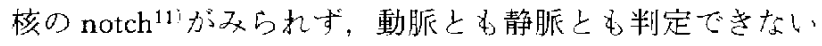
むのですった（Fig. 3)，血管臂の一部が膨隆し，一部には 中隔が形成されていた(Fig. 3C)。さりに, 長軸厅向の血 管 $(30 \mu \mathrm{m}$ 前後)が早期に忺現してくるのが5月月でも判っ た。毛細血管絧は3日目に比へると徐々飞発達してきて出 り，その汪か $10 \mu \mathrm{m}$ 前後の壁不整の血管むよで称じれる持

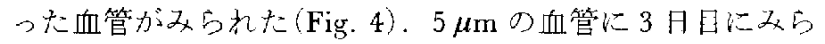
れたのと同様の盲襄形成がみられた。

7 日月になると，毛細血管粡が全域に双ら孙，血管構築

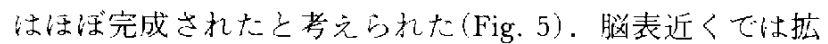
張・蛇行の日立つ血管が5日目同様みられ, さらに法10 $15 \mu \mathrm{m}$ の壁が不整の血管粒が双られ，一部には sinusoid 様 に拡張したところb双られた(Fig. 6A). Fig. 6Bのごと く，螺旋状を呈した血管も又られたが，その周辺の毛細血 管網は5 日日と比へ，その数が增加していた。 しかし，壁 不整の血管は減少し，Fig. 6C のごとく，スムーズな壁炎 持ったほぼ正常の毛細血管網が多く又られた。

\section{$\mathbf{N}$ 考察}

現在をで正常脸4,11,20,21iあるいは種々の疾患6,9,12,13,17,19)に おける血管構築り研究は散見される、しかし，脸浮腫にお

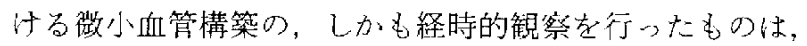
我々が涉椫したがきでは見いらない，血管構築の観察に 対して microangiography が従来より用いられている9,13! か，我々はより立体的に，しかも走査電顕を用いることに より，さらに微小血管を観察することのできる血管鋳型
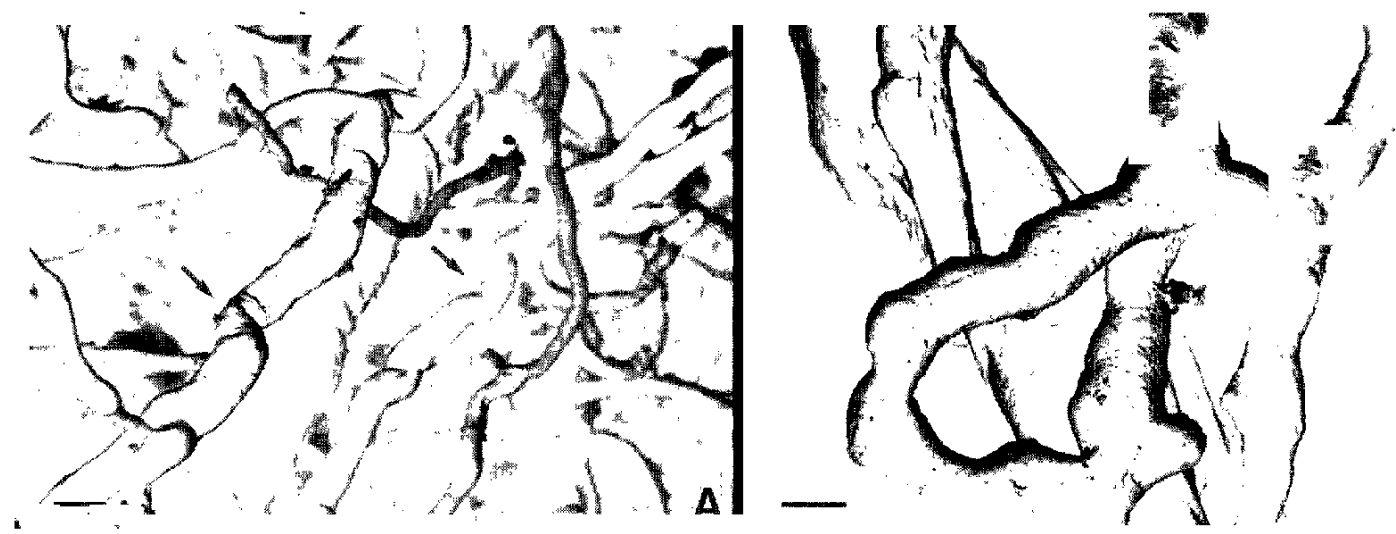

B

Fig. 4 Day 5 after cold injury. A: Many capillaries show kinking (arrows). Bar $=10 \mu \mathrm{m}$. B: Irregular vessel walls in the margin of the edematous zone. $\mathrm{Bar}=10 \mu \mathrm{m}$. 


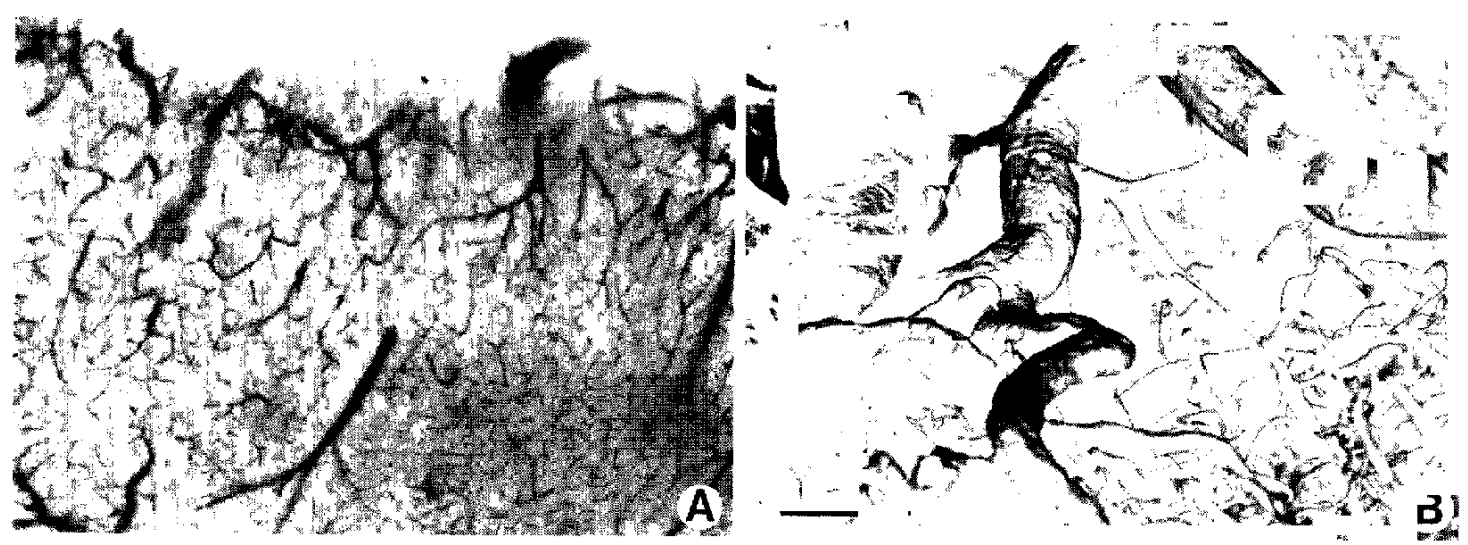

Fig. 5 Day 7 after cold injury. The microvascular architecture of the lesion has been totally reformed. A: Microvasculature demonstrated by colloidal carbon. $\times 40$. B: Scanning electron microgram of vascular cast. Bar $=100 \mu \mathrm{m}$

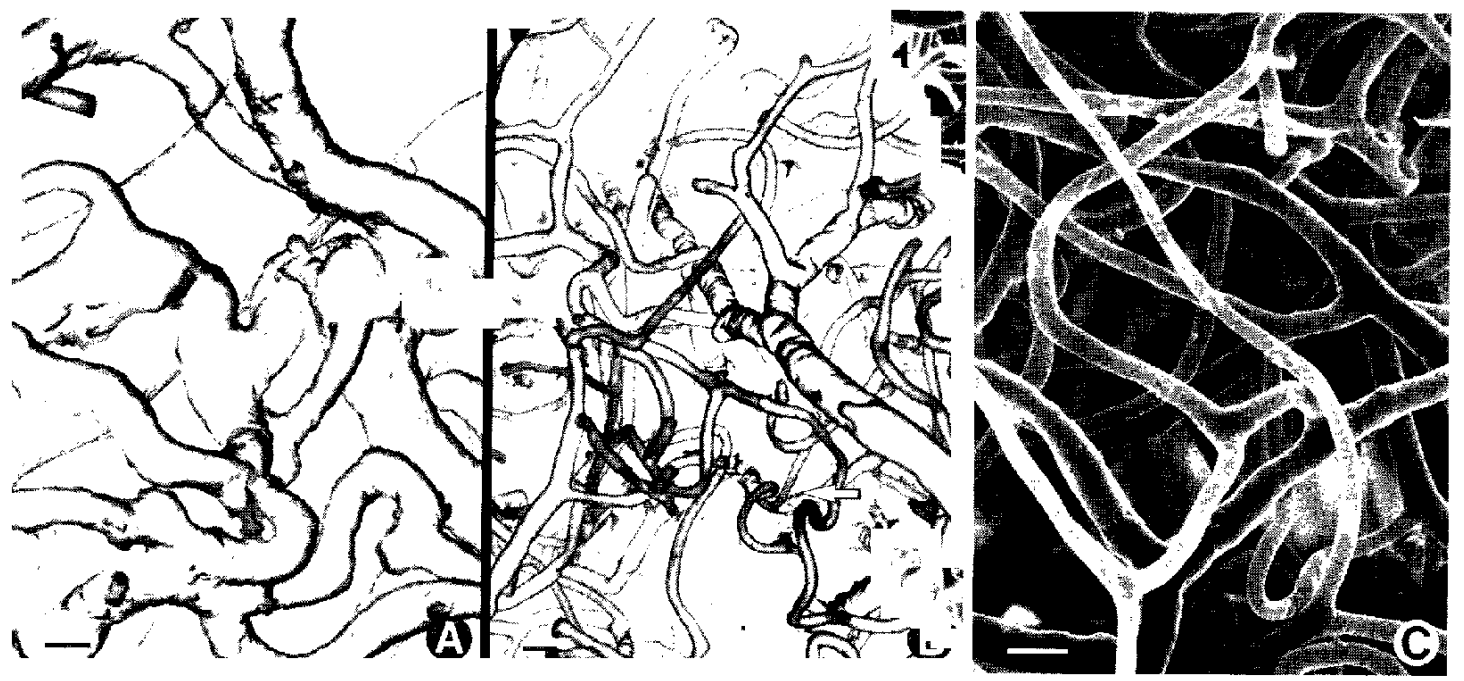

Fig. 6 Day 7 after cold injury. A: Blood vessels with irregular walls at the brain surface and dilated sinusoidal vessels. Bar $=10 \mu \mathrm{m}$. B, G: Smoothly running microvessels with uniform diameters and three-dimensional distribution are visible. Spiral formation of the capillaries (arrow) is demonstrated. $B a r=10 \mu \mathrm{m}$

法们により行った。

この鋳型法の有用吽についてはすで述べられてい $ろ^{12,20)}$ ガ，この力法で閣題になるのはレシンの这入が不完 全なために血管鋳型に久損が生じることである。この問題 を解決与るため私は，血管鋳型標本が断続しているとこ ろではゼラチン加コロイダルカーボンを注入した標本と比 較钼察し，なるべくすべての血管が連続している部を検索

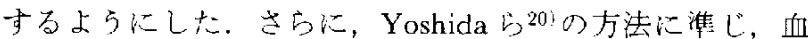

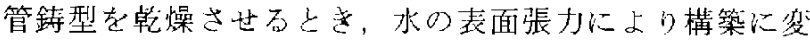
形・虚脱をきたすのを防ぐ目的て凍結真空乾燥走行い，上 り上い試料を得ることができた。
従来，脳浮腫の血管構築を修復といら面上り観察した報 华はないが， cytotoxic cdema の总性期を microangiographyにて観察したもの13)，さらに脳梗塞作製24時間後 の血管棈築を観察し，微小血管が伸展して直線状に走行 し，一部にレジンの血管外流出の所見を認めた報告いは市

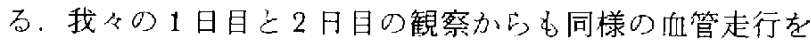
認めている。しかし，レジンがコンブ状に血管外入流出し た所見はなかった。

さて，血管構築の修復は3月目より開始され，7日目に はば完成されることが判った。血管構築の修復は大きく二

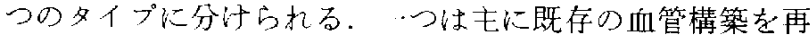


現しながら浮腫周用より修復されるもので，もらーつい脳 表近くの小部分にみられるが，止常ラット脳ではみ的れな い形態をとるものである。この買常血管には種々の形状を

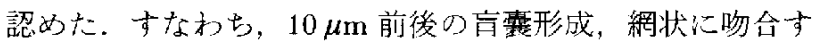
る壁不整の响管網に sinusoid 状に払大した血管，さらに屈 曲・蛇行し，血管壁の一部が膨れ，径が大きいにもかかわ らず，動脈子屯静脈子屯同定できないもの，中隔が形成さ れつつある像などである。このうち $10 \mu \mathrm{m}$ 前後の盲頼形成 は，鋳型法では盲囊部の先がどのようになっているか不明 であるが，透過電影の観察から vascular sprout と考えら れている2,211。また， sinusoid样に搪張した血管は，正常 胎生期にみられるばからでなく21，脳梗塞や知験脳腫

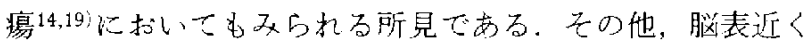

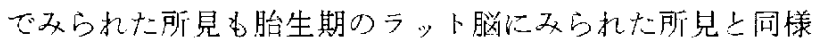
であった211。このことより，これら脳表近くでみられた血 管媇生血管であると思小れる。

ては,どらしてこのよらに二つの型があるのであうら か. 脳浮腫時の血管内皮細胞を経時的に透過電顕で観察し 大報告了てで，通常の場合，基底膜が保存され，内皮細胞 の再生はこの基底膜に㳂ってなさ扎る。しかも，3日月よ り浮腫の周用から再生内皮細胞がみられるという。几か し，基底膜が強く損傷された場合，どのよらになるのかは 検討されていない，今回，私は脳表近くの組織傷害の非常 に強いところての透過電顕での観察を行っていないがおう そらくこの部で基底膜の断裂をたは破壊が方られ，新小 血管にて血管構築の修復が仕されたと思われる。このこと は，上卜胎児脳の血管発牛の初期飞执いて基底膜の非评続 部に未熟な血管が双られたといら報告らときわ的て類似し た所見である、つまり，基底膜が保存されているとこるで は既存の血管構築のま李修復が行加れ，基底膜がある程度 破壊されているところでは新生血管により血管楧築の修復 がなされると思秃る。。

次に，経過中に血管壁の不整が秝られるが，血管構築の 修復とともにその不整が少なくなっている。これらは血管 内血栓と腫大している再生内皮に関倸が每ると思わ机る。 つまり，浮腫の消褪とともに血管内血栓が溶解し16!，また 再生内皮細胞は時間の経過とともに薄くなってくることる゙ に起因していると思われる。

どのようなィカニズム代より血管構築が修復されるのか は定かではない，脳浮腫が軽減されるにしたがって血管構 築が改善してくるのか，それとも血管構築が改善してくる から脳浮腫が軽減してくるのか，一概に法論ずることはて きない，脎浮腫が軽減してくるといら現象は，血管だを 論じて解決するものではなく，グリフ細胞屴よび血液由来 細胞など，代謝面も含めて総合的に考觉なけ机ばならな
ᄂ.

最後に，さらに興棟あることは，Ikutaらうが脳浮腫之 いら細胞外間隌の異常な抬大を示可病態を，細胞の増生や 移動連動に必要な細胞外腔を持っている胎牛期の脳の状熊 に関連付けて考察していることである。彼らによれば，ダ リア細胞による病変修復は，やはり我々の血管構築の結果 乙同様，3日日上り始まっているという。さらに，我々の 観察し九脳表近くの新生血管が胎生期の血管形態上非常に 似ていることは，Ikutaらうの報告を合せ考学ると，非常 に興味深いものでする。

\section{V 結 語}

脳損傷後に伴ら脳浮腫における微小血管構筑の経時的観 察を血管鋳型法により行いた，血管構築の修復は3日日よ

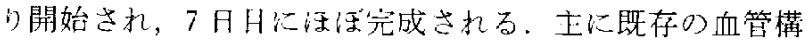
築を再現しつつ，浮腫周团上り修復されるが，脑表近くの 小部分，つをり浮隀の非常に強い部分では血管の新生によ り血管構築の修復がなされる上考它られる。

稿劣終えるに当り，終始变ら奴御指導を賜りました山口大学脸

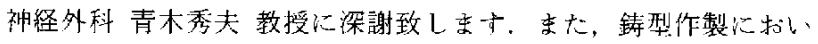
て適切な御助言を戴ききした新鼠大学脳研究所神释病理吉田泰

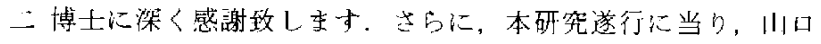
大学脳神释外科 西崎隆文 先生, 原田有应 先牛, 上領俊文 先生 には標本作製で，市村好江婹には写具・文献整理，タイプなと で御協力を戴きました。

本論文の要旨は，第45回日,本脳神経外科学会総会(1986年10月， 東京)に少いて発表した。

\section{文献}

1) Ames A, Wright RL, Kowada M, Thurston JM, Majno G: Cerebral ischemia. The no-reflow phenomenon. Amer $J$ Path 52: $437-453,1968$

2) Bar T, Wolff JR: The formation of capillary basement membranes during internal vascularization of the rat's cerebral cortex. Z Zellforsch 133: 231-248, 1972

3) Cancilla PA, Frommes BS, Kahn LE, DeBault LE: Regeneration of cerebral microvessels. A morphologic and histochemical study after local freeze-injury. Lab Invest 40: 74-82, 1979

4) Fischer ED, Lorenzo AV, Landis WJ, Welch K, Ofori-Kwakye SK, Dorval B, Hodgens KJ, Kerr CS: Vasculature to the germinal matrix in rabbit pups. I Neurosurg 64:650 656, 1986

5) Hauw JJ, Berger B, Escourolle R: Electron microscopic study of the developing capillaries of human brain. Acta Neuropathol (Berl) 31: 229-242, 1975

6) Hekmatpanah J, Hekmatpanah CR: Microvascular alterations following cerebral contusion in rats. Light, scanning and electron 
microscope study. J Neurosurg 62: 888-897, 1985

7) Ikuta F, Yoshida Y, Ohama K, Oyanagi S, Takeda S, Yamazaki K, Watabe K: Revised pathophysiology on BBB damage. The edema as an ingeniously provided condition for cell motility and lesion repair. Acta Neuropathol [Suppl] (Berl) 8: 103110,1983

8) Klatzo I, Chui E, Fujiwara K, Spatz M: Resolution of vasogenic brain edema, in Cevas-Navarro J, Ferszt R (eds) : Brain Edema. New York, Raven, 1980, pp 359-373

9) Kuroiwa $T$, Tsuyumu M, Takei H, Inaba Y: Effects of Nd: YAG and $\mathrm{CO}_{2}$ lasers on cerebral microvasculature. Study in normal rabbit brain. $J$ Neurosurg 64: 128-133, 1986

10) Murakami $T$ : Application of the scanning electron microscope to the study of the fine distribution of the blood vessels. Arch Histal Jap 32: 445-454, 1971

11)中井國雄、今井治通, 龟井一郎, 板倉 徹, 駒井則彦, 木 村 宏，永井利三郎，前田敏博：脳内微小循環と乙の調節機 構に関寸る研究一微細血管樹脂鋳型標本の立体的観察—. Neurol Med Chir (Tokyo) 20:155-161, 1980

12）岡伸夫，中田潤一，遠藤俊郎，高久 晃，篠原治道，森 次左歳：実験的水頭应に拈的血管構築. Neurol Med Chir (Tokyo) 25: 701-706, 1985

13) Perez CA, Hodges FJ, Margulis AR: Microangiography in experimental cerebral edema in rats. Radiology 82: 529-535, 1964

14) Press MF: Lead encephalopathy in neonatal long-evance rats. Morphologic studies. J Neuropathol Exp Neurol 36: 169-195, 1977
15) Reulen HJ, Tsuyumu M, Tack A, Fenske AR, Prioleau GR Clearance of edema fluid into cerebrospinal fluid. A mechanism for resolution of vasogenic brain edema. $J$ Neurosurg 48: 754-764, 1978

16) Segawa H, Patterson RH: Role of platelets in vasogenic brain edema. Significance of thrombus formation in the damaged vessels. Arch Neurol 38: 265-270, 1981

17）堤 健二：脳梗塞に関寸る実験的研究一血管鋳型走査電顕 法老中心に一. Neurol Med Chir (Tokyo) 26:595-600, 1986

18) Vorbrodt AW, Lossinsky AS, Wisniewski HM, Suzuki R, Yamaguchi T, Masaoka H, Klatzo I: Ultrastructural observations on the transvascular route of protein removal in vasogenic edema. Acta Neuropathol (Berl) 66: 265-273, 1985

19）声田泰二：奏験膠腫内微小血管の立体像一胎仔, 新生仔期 ゆ脳血管形成との関連一。脳と神 35:619-627, 1983

20) Yoshida Y, Ikuta F: Three-dimensional architecture of cerebral microvessels with a scanning electron microscope. A cerebrovascular casting method for fetal and adult rats. J Cereb Blood Flow Metabol 4: 290-296, 1984

21) Yoshida $Y$, Ikuta F, Watabe K, Nagata $T$ : Developmental microvascular architecture of the rat cerebellar cortex. Anat Embryol (Berl) 131: 129-138, 1985

〔別刷請求先：干755 山口県宇部市小串 1,144 , 山口大学脳神経 外科, 織田梠至了 